\title{
Differential expression in genes involved in the NF- $\kappa \beta$ pathway among asymptomatic HTLV-1 carriers and HAM/TSP patients in Peru
}

\author{
Michael Talledo ${ }^{1,2^{*}}$, Jason Rosado ${ }^{1,2}$, Carolina Alvarez ${ }^{2,3}$, Daniel Clark ${ }^{2,4}$, Eduardo Gotuzzo $2,5,6$ \\ From 16th International Conference on Human Retroviruses: HTLV and Related Viruses \\ Montreal, Canada. 26-30 June 2013
}

HTLV-1-associated myelopathy/tropical spastic paraparesis (HAM/TSP) is a neuroinflammatory, non-remitting and disabling disease. NF- $\kappa \beta$ pathway plays a role in the pathogenesis of this condition. We compare the expression at peripheral level of 84 genes involved in the NF- $\kappa \beta$ pathway among asymptomatic HTLV-1 carriers (AC) and HAM/ TSP patients. mRNA from PBMCs was isolated from 12 HTLV-1 carriers classified into three groups: fourAC (=patients without any neurological condition) and eight patients with HAM/TSP (four with EDSS scores of 1-5 and four with EDSS score of 5.5-9.0). 84 genes related to the NF- $\kappa \beta$ pathway were evaluated using Superarray plates (SABiosciences) and Real Time PCR in both groups. Ct values under 35 were considered positive, False Discovery Rate was used to control by multiple comparisons. Three genes were dysregulated in HAM/TSP patients. The expression level of NF- $\kappa \beta$ IA was higher in AC compared to HAM/TSP patients, while EGR1 and IL-8 showed a lower expression in AC compared to HAM/TSP patients $(\mathrm{p}<0.05$ after multiple testing correction). These results are in agreement to our previous genetic findings; nevertheless, a validation in an independent group is required to confirm these results. Further studies evaluating the role of genes involved in the NF- $\kappa \beta$ pathway as potential biomarkers for HAM/TSP are needed.

\section{Authors' details}

'Laboratorio de Epidemiología Molecular, Universidad Peruana Cayetano

Heredia, Lima, Peru. ${ }^{2}$ Instituto de Medicina Tropical Alexander von Humboldt, Universidad Peruana Cayetano Heredia, Lima, Peru. ${ }^{3}$ Rega Institute for Medical Research, Katholieke Universiteit Leuven, Leuven, Belgium. ${ }^{4}$ Laboratorios de Investigación y Desarrollo, Universidad Peruana

\footnotetext{
* Correspondence: michael.talledo.a@upch.pe

'Laboratorio de Epidemiología Molecular, Universidad Peruana Cayetano Heredia, Lima, Peru

Full list of author information is available at the end of the article
}

Cayetano Heredia, Lima, Peru. ${ }^{5}$ Facultad de Medicina, Universidad Peruana Cayetano Heredia, Lima, Peru. ${ }^{6}$ Hospital Nacional Cayetano Heredia, Lima, Peru.

Published: 7 January 2014

doi:10.1186/1742-4690-11-S1-P126

Cite this article as: Talledo et al: Differential expression in genes involved in the NF- $\kappa \beta$ pathway among asymptomatic HTLV-1 carriers and HAM/TSP patients in Peru. Retrovirology 2014 11(Suppl 1):P126.

Submit your next manuscript to BioMed Central and take full advantage of:

- Convenient online submission

- Thorough peer review

- No space constraints or color figure charges

- Immediate publication on acceptance

- Inclusion in PubMed, CAS, Scopus and Google Scholar

- Research which is freely available for redistribution 